\title{
Post-chemotherapy neuropathy
}

\author{
Neuropatia pós-quimioterapia
}

Ricardo Caponero', Emily Santos Montarroyos², Silvia Maria Machado Tahamtani ${ }^{3}$

DOI 10.5935/1806-0013.20160049

\section{ABSTRACT}

BACKGROUND AND OBJECTIVES: Anticancer chemotherapeutics can induce painful peripheral neuropathy. Symptoms range widely and can involve sensory, motor, and autonomic systems. However, chemotherapyinduced peripheral neuropathy is under-assessed and undertreated and its diagnosis is somewhat complicated by the lack of consensus on its pathophysiology and presentation. The objective of this study was to review medical publications in English, Spanish and Portuguese, in the last ten years, about painful peripheral neuropathy.

CONTENTS: Systematic literature review on painful peripheral neuropathy associated with systemic anticancer chemotherapy.

CONCLUSION: Although limited reliable evidence regarding the appropriate treatment for this condition exists, it is based on current neuropathic pain guidelines. Further studies on differences between the pathophysiology of chemotherapy-induced peripheral neuropathy and those of other neuropathic pain conditions may lead to the development of more effective treatment modalities. Additionally, therapeutic strategies for the management of chemotherapy-induced peripheral neuropathy must be validated by large-scale randomized clinical trials to meet the demands of evidenced-based medicine. Keywords: Adverse effects, Chemotherapy, Neuropathy, Neuropathic pain.

\section{RESUMO}

JUSTIFICATIVA E OBJETIVOS: A quimioterapia antineoplásica pode induzir a neuropatia periférica dolorosa. Os sintomas variam amplamente e podem envolver o sistema sensitivo, motor e autonômico. Contudo, a neuropatia periférica induzida por quimioterapia é subavaliada e subtratada e tem seu diagnóstico postergado pela falta de um consenso em sua fisiopatologia e apresentaçáo. O objetivo deste estudo foi rever trabalhos publicados em português, inglês ou espanhol nos últimos 10 anos, a respeito da fisiopatologia e tratamento da neuropatia periférica dolorosa.

CONTEÚDO: Revisão bibliográfica, sistemática, sobre neuropatia periférica dolorosa associada à quimioterapia sistêmica antineoplásica.

CONCLUSÁO: Embora existam limitadas evidências confiáveis a respeito do tratamento apropriado dessa condição, ela é fundamentada nas diretrizes gerais para o tratamento da dor neuropática. Estudos subsequentes devem levar em consideração as diferenças na fisiopatologia da neuropatia periférica induzida pela quimioterapia de outras condiçóes de neuropatia dolorosa, que possam levar ao desenvolvimento de modalidades de tratamento mais efetivas. Adicionalmente, estratégias terapêuticas para o tratamento de neuropatia periférica induzida pela quimioterapia precisarão ser validadas em estudos clínicos randomizados de larga escala, a fim de satisfazer as demandas da medicina baseada em evidências.

Descritores: Dor neuropática, Efeitos adversos, Neuropatia, Quimioterapia.

1. Clínica de Oncologia Médica SC Ltda, Departamento de Oncologia, (Instituto de Estudios Biosanitários de Madri), São Paulo, SP, Brasil.

2. Médica Anestesiologista com Área de Atuaçáo em Terapia da Dor e Medicina Paliativa (SBA/AMB). Mestre em Medicina Tropical, Manaus, AM, Brasil.

3. Médica Anestesiologista e Algologista, Médica assistente no Centro Multidisciplinar de Tratamento da Dor - Instituto do Câncer do Estado de São Paulo. Sáo Paulo, SP, Brasil.

Conflict of interests: none - Sponsoring sources: none.

\section{Correspondence to:}

Ricardo Caponero

Av. Nove de Julho, 4634 - Jardim Paulista

01406-100 São Paulo, SP, Brasil.

E-mail: ricapone@uol.com.br

(C) Sociedade Brasileira para o Estudo da Dor

\section{INTRODUCTION}

Anti cancer chemotherapy-induced peripheral neuropathy (IPN) is an adverse event present in approximately $38 \%$ of patients being treated with multiple agents, although this percentage may vary depending on drug, dose, exposure duration, comorbidities (especially alcoholism and diabetes), association with other treatments (surgery, radiotherapy, etc.) evaluation methods and time it takes to appear with regard to anti-cancer treatment ${ }^{1}$.

A literature review involving 31 studies and 4179 patients has shown prevalence of chemotherapy-induced neuropathy of $68.1 \%$ (95\% confidence interval (CI95\%): $57.7 \%-78.4 \%)$ when measured in the first month after chemotherapy; $60.0 \%(36.4 \%-81.6 \%)$ at three months; $30.0 \%(6.4 \%-53.5 \%)$ at six months or more 2 .

Standardization of evaluation methods is critical for the accurate determination of incidence, grade and impact on quality of life $(\mathrm{QL})^{3}$.

Characteristically, neuropathy is associated to dysesthesia and pain, which affect QL and may become a very significant sequela for a long time in cancer survivors ${ }^{4}$. Higher intensity presentations may result in decreased chemotherapy doses and early treatment interruption, thus impairing its efficacy ${ }^{5}$.

The importance of preventing and treating pain associated to chemotherapy-IPN increases as anti-cancer treatment provides and residual neuropathy after treatment may persist for a significantly long period, deteriorating survivors' quality of life. Since 1970, the number of cancer survivors has tripled and today they are approximately 28 million worldwide and in whom late or long lasting adverse effects have major impact. Since potentially neurotoxic drugs are widely used for tumors of higher incidence, it is estimated the major impact of chemotherapy-IPN ${ }^{5}$.

\section{NEUROPATHY-INDUCING CHEMOTHERAPEUTIC DRUGS}

Combinations of chemotherapeutic drugs with highest peripheral neurotoxicity rates include those involving platinum salts (cisplatin, carboplastin and oxaliplatin), vinca alkaloids (vincristine, vimblastine, vinorelbine), bortezomib (proteasome inhibitor) and taxanes (paclitaxel, docetaxel, cabazitaxel) ${ }^{6}$.

In addition to dose and time-dependent chronic neuropathy, some agents such as taxanes and oxaliplatin may induce a characteristic acute neuropathy syndrome triggered by cold and sometimes associated to pharyngolaryngeal dysesthesia. In this aspect, acute neurotoxicity which starts within hours or days after oxaliplatin infusion deserves special considerations ${ }^{7}$.

Oxaliplatin is primarily used to treat colorectal adenocarcinoma. Animal studies suggest changes in the level of regulatory and structural proteins in central nervous system (CNS) and spinal cord which may be directly implied in oxaliplatin-induced acute neurotoxicity ${ }^{7}$.

The combination of a platinum salt and a taxane is the treatment of choice for ovarian epithelial tumors. In this context, chemotherapy- IPN is often an adverse event of the treatment which may limit its administration and a new treatment cycle, thus impacting patients' survival in case of recurrence, since neuropathy often lasts beyond the recurrence period ${ }^{8}$. Bortezomib is a proteasome inhibitor used to treat recently diagnosed or recurrent myeloma and mantle cells lymphoma.

Bortezomib-induced NP is considered its major non-hematologic toxicity, in general resulting in dose change do to its severity. Underlying mechanism is still not totally understood ${ }^{2}$.

\section{PATHOPHYSIOLOGY}

Although pathogenesis and toxicity profiles differ among potentially neurotoxic agents, there are some features which allow the differentiation of 
chemotherapy-induced NP from those induced by other causes. Classically, many chemotherapeutic drugs causing peripheral neuropathy do it symmetrically, distal, with "boot and glove" distribution. This neuropathy is more sensory than motor and symptoms are progressive and dependent on agents, doses and treatment duration ${ }^{10}$.

Different chemotherapeutic drugs affect different nervous system components, from dorsal root ganglion cells to the distal axon ${ }^{11}$. Dorsal root ganglion, for being less protected by the nervous-blood barrier, is more vulnerable to neurotoxicity. This explains the predominance of sensory manifestation is patients affected by neuropathy ${ }^{12,13}$.

A common finding in nervous conduction studies is a sensory axonal injury with decreased action potentials amplitude, which may result from more complex cell changes resulting from mitochondrial alterations ${ }^{14}$, interference with microtubules; qualitative neuronal membrane changes, oxidative stress ${ }^{15}$ and neuronal apoptosis ${ }^{16}$.

\section{Clinical presentation}

Oxaliplatin-induced acute sensory neuropathy starts in a time interval which varies from drug administration moment to 3 to 5 days after it, may persist for days to months and have its intensity and duration increased with the sequence of treatment cycles. Its installation is acute and of rapidly progressing intensity, lasts for a variable period and tends to decrease in intensity some days later. Chemotherapy-INP pain affects more than $90 \%$ of patients under treatment ${ }^{17,18}$, is in general triggered by cold, affecting distal limbs, mouth, jaw pain when biting and mouth paresthesia ${ }^{19,20}$ and may be simultaneous with pharyngolaryngeal dysesthesia ${ }^{21}$. There might also be muscle spasms, fasciculations and cramps $^{20}$.

Oxaliplatin chronic sensory neuropathy is dose-cumulative, with progressively increasing intensity along treatment, and is primarily manifested by sensitivity to cold, hypoesthesia (numbness) and dysesthesia (tingling) in hands and feet, joint pain, muscle weaknes and balance changes ${ }^{22}$.

It affects $30-50 \%$ of patients and may last for years after the end of chemotherapy ${ }^{23,24}$. Patients adapt to chronic symptoms but sensory deficits last for a long time ${ }^{25-29}$. Lack of support and follow up of these patients may lead them to depression, sleep disorders and significant QL impairment ${ }^{27,29}$.

Bortezomib-induced NP is predominantly sensory, causing paresthesia and numbness in disal areas, especially lower limbs ${ }^{30}$;

\section{Diagnosis}

As a function of characteristic clinical presentation and direct correlation with chemotherapy, diagnosis is often established by history and physical evaluation, not needing additional exams ${ }^{1}$. Patients should be previously evaluated to identify other pre-existing sensory neuropathy causes, such as diabetic neuropathy. The correlation between onset and progression of neuropathic symptoms and chemotherapy duration also helps the identification of such patients.

Electroneuromyography shows a predominantly sensory, peripheral and symmetrical neuropathy pattern. It seldom supplies data adding relevant information to clinical data, in addition to causing significant discomfort to patients ${ }^{26}$.

\section{Predictive factors of chemotherapy-induced peripheral neuropathy}

Broad genoma analyses have described some single-nucleotide polymorphisms (SNP) associated to higher susceptibility, but are not applicable to current clinical practice ${ }^{2}$.

In addition to type of chemotherapeutic drug, dose, onset time ${ }^{26}$ and treatment, some other clearly associated factors to chemotherapy-IPN have been described and include: baseline neuropathy by other cause, smoking and increased serum creatinine ${ }^{2}$. Neuropathy secondary to diabetes mellitus, alcoholism and specific nutritional defficiencies deserve special attention in Brazilil ${ }^{27}$.

\section{Prevention}

The best way to prevent chemotherapy-induced NP is not using agents which produce this adverse event. However, major therapeutic classes (platinum salts, taxanes and vinca alkaloids) have this toxicity and can hardly be replaced without imparing therapeutic efficacy of the anticancer regimen ${ }^{19}$.
In palliative treatment it is possible to withdraw medication when the adverse event becomes more evident, after considering the toxicity-benefit ratio. However, curative treatment regimens or those having major impact on disease evolution can be hardly replaced.

Calcium gluconate, magnesium taxasulfate, vitamins and other compounds have no proven efficacy to prevent neuropathy and are not recommended for this purpose. The only exception seems to be venlafaxine to prevent acute neuropathic pain specifically induced by oxaliplatin. Although there is improvement in the acute symptom, there are no evidences of the same benefit for chronic neuropathy.

According to the American Society of Clinical Oncology (ASCO) guide-

line, due to the lack of high quality data with consistent evidences, there is no agent recommended to prevent chemotherapy-induced $\mathrm{NP}^{29}$.

\section{Treatment}

Neuropathic pain treatment shall be discussed in a different topic of this publication, but here one should stress neuropathic pain secondary to chemotherapy-induced NP because there is a specific guideline for it ${ }^{20}$.

According to ASCO, best available data on already installed chemotherapy-INP treatment support a moderate recommendation for treatment with duloxetine ${ }^{30}$. Although chemotherapy-INP studies are inconclusive about tricyclic antidepressants (such as notriptyline), gabapentin and other topic preparations with baclofen, amitriptyline and ketamine, these agents might be prescribed based on data supporting their usefulness for neuropathies of other causes ${ }^{20}$.

A more recent systematic review and meta-analysis supports a review of recommendations for neuropathic pain pharmacologic therapy. Especially the number of patients needed to treat (NNT), combining the studies, is $6.4(95 \%$ confidence interval (CI95\%): $5.2-8.4)$ for serotonin and norepinephrine reuptake inhibitors, especially including duloxetine (9 out of 14 studies); $7.7(6.5-9.4)$ for pregabalin; $7.2(5.9-9.21)$ for gabapentin, including extended release formulation and enacarbil; and 10.6 (7.4 - 19.0) for patches with high capsaicin concentration ${ }^{31}$.

According to this review, considering costs and adverse events, findings provide strong recommendation for the use and the proposition as first line treatment for neuropathic pain of tricyclic antidepressants, serotonin and norepinephrine reuptake inhibitors, pregabalin and gabapentin. There is a weaker recommendation and a proposal for second line treatment for lidocaine patches or high capsaicin concentrations, and systemic tramadol. There is a weak recommendation and proposal for third line treatment for strong opioids ${ }^{32}$.

Inadequate responses to neuropathic pain relief are a medical need not met for chemotherapy-INP patients. Modest efficacy, good responses to placebo, heterogeneous diagnostic criteria, variability in evaluation of efficacy and different phenotypes among patients are probably responsible for modest clinical trials results and shall be taken into consideration by further studies ${ }^{22}$.

Data on the use of acupuncture or electroacupuncture, as well as natural products of complementary medicine do not supply enough evidence for any clinical recommendation to treat chemotherapy-induced neuropathic pain ${ }^{23}$.

Since there is no defined pharmacological treatment, if any, focus should be on patients' care and should promote education, explaining to patients and their families about potentially expected events; minimizing falls and risk of injuries due to hypoesthesia; changing lifestyle and labor activities and avoiding risk factors worsening neuropathy ${ }^{5}$.

\section{CONCLUSION}

Chemotherapeutic drugs with highest potential for adverse PNS events are among those most widely used, which makes peripheral sensory neuropathy a common event with major impact on patients' quality of life. It may lead to changes in treatment regimens with loss of effectiveness, as well as to chronic sequelae and incapacity.

It is not always feasible to change anti-cancer therapeutic regimen, but early identification and adequate treatment of symptoms associated to peripheral sensory neuropathy may decrease its impact on QL. In patients under palliative care, the use of alternative regimens should be considered after weighing potential benefits versus adverse events. 


\section{REFERENCES}

1. Cavaletti G, Frigeni B, Lanzani F, Mattavelli L, Susani E, Alberti P, et al. Chemotherapy-Induced Peripheral Neurotoxicity assessment: A critical revision of the currently available tools. Eur J Cancer. 2010;46(3):479-94

2. Seretny M, Currie GL, Sena ES, Ramnarine S, Grant R, MacLeod MR, et al. Incidence, prevalence, and predictors of chemotherapy-induced peripheral neuropathy: a systematic review and meta-analysis. Pain. 2014;155(12):2461-70.

3. Cavaletti G, Cornblath DR, Merkies ISJ, Postma TJ, Rossi E, Frigeni B, et al. The chemotherapy-induced peripheral neuropathy outcome measures standardization study: from consensus to the first validity and reliability findings. Ann Oncol. 2013;24(2):454-62.

4. Hershman DL, Weimer LH, Wang A, Kranwinkel G, Brafman L, Fuentes D, et al. Association between patient reported outcomes and quantitative sensory tests for measuring long-term neurotoxicity in breast cancer survivors treated with adjuvant paclitaxel chemotherapy. Breast Cancer Res Treat. 2011;125(3):767-74

5. Park SB, Goldstein D, Krishnan AV, Lin CS, Friedlander ML, Cassidy J, et al. Chemotherapy-induced peripheral neurotoxicity: a critical analysis. CA Cancer J Clin. 2013;63(6):419-37.

6. Pachman DR, Barton DL, Watson JC, Loprinzi CL. Chemotherapy-Induced Peripheral Neuropathy: Prevention and Treatment. Clin Pharmacol Ther. 2011;90(3):377-87.

7. Gamelin E, Gamelin L, Bossi L, Quasthoff S. Clinical aspects and molecular basis of oxaliplatin neurotoxicity: current management and development of preventive measures. Semin Oncol. 2002;29(5):21-33.

8. Sanna MD, Ghelardini C, Galeotti N. Altered expression of cytoskeletal and axonal proteins in oxaliplatin-induced neuropathy. Pharmacology. 2016;97(3-4):146-50.

9. Brewer JR, Morrison G, Dolan ME, Fleming GF. Chemotherapy-induced peripheral neuropathy: current status and progress. Gynecol Oncol. 2016;140(1):176-83.

10. Carozzi VA, Canta A, Chiorazzi A. Chemotherapy-induced peripheral neuropathy: what do we know about mechanisms? Neurosci Lett. 2015;596:90-107.

11. Allen DT, Kiernan JA. Permeation of proteins from the blood into peripheral nerves and ganglia. Neuroscience. 1994;59(3):755-64.

12. Gregg RW, Molepo JM, Monpetit VJ, Mikael NZ, Redmond D, Gadia M, et al. Cisplatin neurotoxicity: the relationship between dosage, time, and platinum concentration in neurologic tissues, and morphologic evidence of toxicity. J Clin Oncol. 1992;10(5):795-803.

13. Krarup-Hansen A, Rietz B, Krarup C, Heydorn K, Rorth M, Schmalbruch H. Histology and platinum content of sensory ganglia and sural nerves in patients treated with cisplatin and carboplatin: an autopsy study. Neuropathol Appl Neurobiol. 1999;25(1):29-40.

14. Flatters SJ. The contribution of mitochondria to sensory processing and pain. Prog Mol Biol Transl Sci. 2015;131:119-46.

15. Han Y, Smith MT. Pathobiology of cancer chemotherapy-induced peripheral neuropathy (CIPN). Front Pharmacol. 2013;4:156-71.
16. Cashman CR, Höke A. Mechanisms of distal axonal degeneration in peripheral neuropathies. Neurosci Lett. 2015;596:33-50

17. Beijers AJ, Mols F, Vreugdenhil G. A systematic review on chronic oxaliplatin-induced peripheral neuropathy and the relation with oxaliplatin administration. Support Care Cancer. 2014;22(7):1999-2007.

18. Tofthagen C. Surviving chemotherapy for colon cancer and living with the consequences. J Palliat Med. 2010;13(11):1389-91.

19. André T, Boni C, Navarro M, Tabernero J, Hickish T, Tophan C, et al. Improve overall survival with oxaliplatin, fluorouracil, and leucovorin as adjuvant treatment in stage II or III colon cancer in the MOSAIC trial. J Clin Oncol. 2009;27(19):3109-16.

20. Wilson RH, Lehky T, Thomas RR, Quinn MG, Floeter MK, Grem JL. Acute oxaliplatin-induced peripheral nerve hyperexcitability. J Clin Oncol. 2002;20(7):1767-74.

21. Sereno M, Gutiérrez-Gutiérrez G, Gómez-Raposo C, López-Gómez M, Merino-Salvador M, Tébar FZ, et al. Oxaliplatin induced-neuropathy in digestive tumors. Crit Rev Oncol Hematol. 2014;89(1):166-78.

22. Han JW, Han S. Type of chemotherapy-induced peripheral neuropathy, influencing factors, and functional status. Iran J Public Health. 2015;44(12):1701-3.

23. Beijers AJ, Mols F, Vreugdenhil G. A systematic review on chronic oxaliplatin-induced peripheral neuropathy and the relation with oxaliplatin administration. Support Care Cancer. 2014;22(7):1999-2007.

24. Tofthagen C. Surviving chemotherapy for colon cancer and living with the consequences. J Pallia Med. 2010;13(11):1389-91.

25. Schneider BP, Hershman DL, Loprinzi C. Symptoms: Chemotherapy-Induced Peripheral Neuropathy. Adv Exp Med Biol. 2015;862:77-87.

26. Cavaletti G, Frigeni B, Lanzani F, Mattavelli L, Susani E, Alberti P, et al. Chemotherapy-induced peripheral neurotoxicity assessment: a critical revision of the currently available tools. Eur J Cancer. 2010;46(3):479-94.

27. Fallon MT. Neuropathic pain in cancer. Br J Anaesth. 2013;111(1):105-11.

28. Saad M, Tafani C, Psimaras D, Ricard D. Chemotherapy-induced peripheral neuropathy in the adult. Curr Opin Oncol. 2014;26(6):634-41.

29. Hershman DL, Lacchetti C, Dworkin RH, Lavoie Smith EM, Bleeker J, Cavaletti G, et al. Prevention and management of chemotherapy-induced peripheral neuropathy in survivors of adult cancers: American Society of Clinical Oncology Clinical Practice Guideline. J Clin Oncol. 2014;32(18):1941-67.

30. Wickham R. Review of a study of duloxetine for painful chemotherapy-induced peripheral neuropathy. J Adv Pract Oncol. 2013;4(5):361-8.

31. Finnerup NB, Attal N, Haroutounian S, McNicol E, Baron R, Dworkin RH, et al. Pharmacotherapy for neuropathic pain in adults: a systematic review and meta-analysis. Lancet Neurol. 2015;(14):162-73

32. Brami C, Bao T, Deng G. Natural products and complementary therapies for chemotherapy-induced peripheral neuropathy: a systematic review. Crit Rev Oncol Hematol. 2016;98:325-34. 